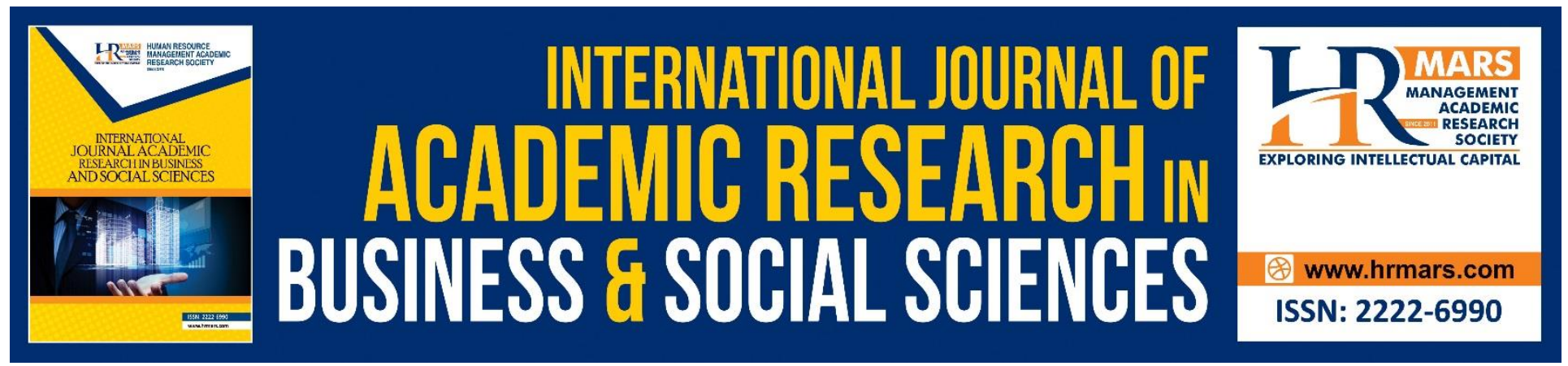

\title{
Delve Into the Challenges of Career Retention among Women Engineer: The Application of the Modified Delphi Technique
}

\author{
Ummu Sakinah Subri, Ridzwan Che' Rus, Ramlee Mustapha, Zaliza Hanapi
}

To Link this Article: http://dx.doi.org/10.6007/IJARBSS/v9-i3/5742

DOI: $\quad 10.6007 /$ IJARBSS/v9-i3/5742

Received: 28 Jan 2019, Revised: 21 Feb 2019, Accepted: 15 March 2019

Published Online: 21 March 2019

In-Text Citation: (Subri, Rus, Mustapha, \& Hanapi, 2019)

To Cite this Article: Subri, U. S., Rus, R. C., Mustapha, R., \& Hanapi, Z. (2019). Delve Into the Challenges of Career Retention among Women Engineer: The Application of the Modified Delphi Technique. International Journal of Academic Research in Business and Social Sciences, 9(3), 767-773.

Copyright: (C) 2019 The Author(s)

Published by Human Resource Management Academic Research Society (www.hrmars.com)

This article is published under the Creative Commons Attribution (CC BY 4.0) license. Anyone may reproduce, distribute, translate and create derivative works of this article (for both commercial and non-commercial purposes), subject to full attribution to the original publication and authors. The full terms of this license may be seen

at: $\underline{\text { http://creativecommons.org/licences/by/4.0/legalcode }}$

Vol. 9, No. 3, 2019, Pg. 767 - 773

http://hrmars.com/index.php/pages/detail/IJARBSS

JOURNAL HOMEPAGE

Full Terms \& Conditions of access and use can be found at http://hrmars.com/index.php/pages/detail/publication-ethics 


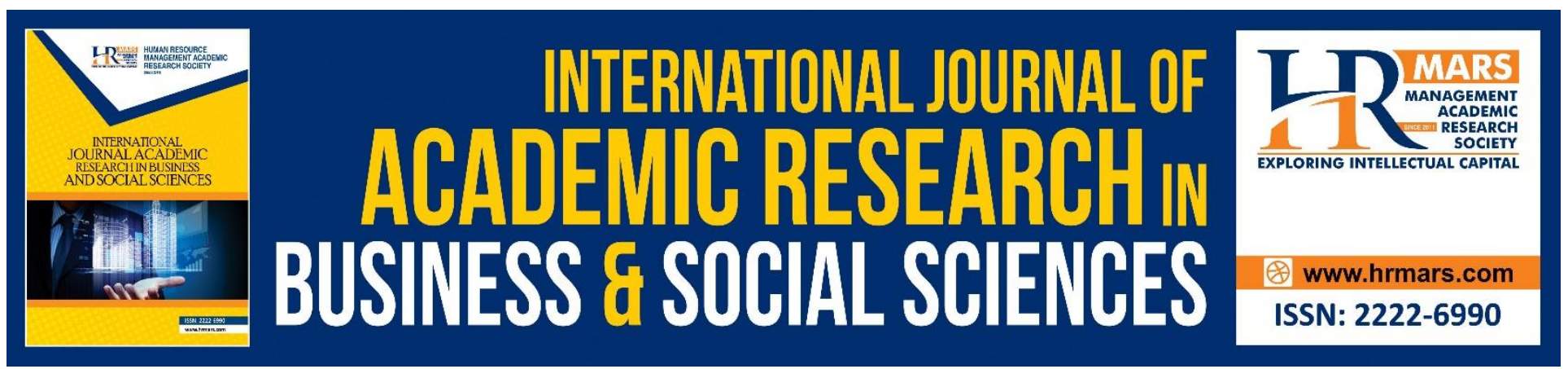

\title{
Delve Into the Challenges of Career Retention among Women Engineer: The Application of the Modified Delphi Technique
}

\author{
Ummu Sakinah Subri, Ridzwan Che' Rus, Ramlee Mustapha, Zaliza \\ Hanapi
}

Universiti Pendidikan Sultan Idris, Tg. Malim, Perak. Malaysia

\begin{abstract}
Women can never be separated from the issue of family commitment in their careers after marriage. The involvement of female engineer shows that it starts to become less and less as the years went by due to the married women facing more conflicts and challenges when they are trying to have a balance between their career and family. Career challenges are anything that prevents future movements from developing or making any progress or any incidents and conditions that make the career development difficult to move forward. Therefore, this study aims to obtain a consensus or an expert agreement regarding career challenges among female engineer who are married. The technique used in this study to identify career challenges is the Modified Delphi Technique. This technique is very suitable and appropriate for exploring new views and opinions taken from a sevenselected panel of experts in an interview with the researchers. With the results obtained from the interview and the approvals from the seven-selected panel of experts, the researchers construct a questionnaire instrument in which it consists of the element of challenges and the items for each challenge. Furthermore, this technique was carried out for three rounds, which started with the expert panel interviews and was followed by a series of a questionnaire survey in the second and third rounds. This cycle of Modified Delphi Technique was then halted when the agreement value or a consensus had been reached by all the panel of experts based on the analysis of Interquartile range (IQR) that has been made.
\end{abstract}

Keywords: Career challenges, Modified Delphi Technique, Interquartile range (IQR)

\section{Introduction}

The establishment of Human Resource Development (HRD) is to act as a producer or creator and as the supplier of the workforce, whether skilled or semi-skilled labours in accordance with the changes in technology and market as well as preparing skills needed in the future. In addition, the main responsibility of the Human Resource Development (HRD) is to provide flexible, agile, knowledgeable 
and with a relevant skilled workforce (Biden \& Kamin, 2013). A good and solid planning for the country has attracted women's attention to work, as such presented in the employment statistics report based on gender in 2013, which shows that the number of female workers in the field of professional occupation is ahead of men, where the number of women recorded is $55.4 \%$ while men are 44.6\% (Tunku Ahmad, Wan Mustapha, Yusof, Zakaria, \& Wan Mazlan, 2015). However, based on the study by Amin and P. Rameli (2014), they found that the challenge for women who are married and at the same time have their own career is very much put a test to their mental strength and endurance, when it comes to problems such as child care, family management, unsuitable work environment, and the conflicts that arise in order to maintain a work-life balance. Thus, as the years went by, there is less participation of women in the workforce.

There are many female labour force that started to leave the job sector, especially in the engineering sector despite a wide-open opportunity for them to gain promotion that comes with all the experiences they have. This career transition is due to the personal commitments of women in the household (Economic Transformation Programme Annual Report, 2014). As stated in the study by Balakrishnan, Foon, and Azman, (2014), the number of female graduates in engineering in 2010 was uneven with the number of engineers in the following year. Furthermore, from the statistics recorded in the Board of Engineers Malaysia Annual Report (2017), it shows that there is a total of 10,413 registered engineers, and from the total number of registered engineers there is only a total of 745 female engineers registered. Fouad, Singh, Fitzpatrick, and Liu (2012) also pointed out that female engineers are very much inclined to quit their job after marriage because of their duties to manage and care for the family, which is much more important than their careers especially after having a child or children under six years old (Snyder, 2011). Therefore, this study was conducted to identify the challenges faced by female engineers by using the Modified Delphi Technique.

\section{Research Methodology}

This study has been conducted using the Modified Delphi Technique. The Modified Delphi Technique is a research process that is conducted by collecting and analyzing the opinion of a group of experts in the chosen field of study. In relation to the field of social sciences, (Grisham, 2009) reckons that Delphi's technique is able to determine the actual items more systematically and able to achieve a higher value of accuracy. This is because these techniques can offer different perspectives and more detailed research in resolving a concerned issue (Hsu \& Sandford, 2007). One of the advantages of using the Delphi technique is that while the technique was carried out, the panel of experts does not have to face each other and the experts can convey their opinion or view without being influenced by other panels (Nworie, 2011; Avella, 2016). Therefore, the technique used in this study is the threeround Modified Delphi Technique and as the technique is ideal for three-round is because to avoid the panel of experts feeling fatigue (Alaloul, Liew, \& Zawawi, 2015).

The total number of expert panels being chosen are varied according to the researcher. There is still no decision has been made regarding the number of expert panels that can participate in a study which needs to be followed by in accordance to a certain standard, whether a small or larger group of experts to be required by the Delphi's researchers (Thangaratinam \& Redman, 2005; Avella, 2016). This is because the number of representations is being evaluated is not by the number of experts present, but the evaluation is made based on the quality of the expert panels (Thangaratinam 
\& Redman, 2005). From the previous researchers, some of them have presented a few stances, such as Linstone, and Turoff (1976) that suggested the minimum size of expert panels which appropriate is seven people but to be more accurate it is between four to 3000 people. However, the Delphi's panel is sufficient between five to 10 people if the experts are of different expertise (Clayton, 1997). Meanwhile, according to Rowe, Evaluations, and Wright (2001), which stated that the number of experts involved is ranged between five to 20 experts. In accordance with the previous researcher's standpoint, the researcher has decided that the number of Delphi's experts involved in this study is a total of seven people based on the suitability within that range of views. The seven appointed specialists comprise two academicians from the Higher Education Institution (HEI) and five experts in the Department of Civil Engineering from the private companies.

\section{Modified Delphi Technique}

The process of this technique consists of three rounds in which the first round started with an interview with the expert panels aimed at identifying the elements of career challenges among female engineers. However, before the interview can be conducted, the set of interview questions that have been prepare needs to be first checked and confirmed its face and content validity by the experts. The type of interviews that have been conducted are semi-structured interviews which focus only on the titles and the proposed scopes. The results obtained from the interviews will form the premise for the construction of questionnaire instrument items used in the second round of this technical study. With the findings on the first round (panel of experts' interview), alongside the reviews of literature analysis from the previous research sources and then combined it with the reports of careers in engineering, the researchers then construct the items and elements for the questionnaire instruments. List of elements that have been agreed by the panel of experts regarding career challenges are as follows;

i. Gender Discrimination

ii. Life Balance

iii. Childcare

iv. Leave of absence

A set of questionnaire was constructed based on a set of questionnaire forms from the previous researcher. The researchers have adapted the items from the previous research with the elements that have been acquired in the first round of the interview. Once a set of the questionnaire has been established, the second round started with the researchers having another discussion with each expert panel and explains the related questionnaire that was constructed. The researchers also explain the definition and the concept of elements that had been agreed by all panel of experts in the first round (interview). Subsequently, the panel of experts will be given the time within two weeks to assess and state their level of agreement regarding the items specified in the questionnaire that has been constructed. Moving forward, based on the feedback obtained from each panel of experts through the questionnaire instruments, the researchers then analyzed the questionnaire instrument items based on the Interquartile range (IQR) analysis to obtain a level of agreement or consensus among the panel of experts on each item. According to the value of IQR, the level of agreement among the experts for each item of the questionnaire was recorded. The level of agreement of the same answer among the experts is determined based on Table 1 as shown below; 
INTERNATIONAL JOURNAL OF ACADEMIC RESEARCH IN BUSINESS AND SOCIAL SCIENCES

Vol. 9, No. 3, March, 2019, E-ISSN: 222 2-6990 @ 2019 HRMARS

Table 1

A Three-point Modified Scale

\begin{tabular}{lcl}
\hline Level of agreement & The Modified Scale & Result \\
\hline High level of consensus & 0 to 1.00 & Item accepted \\
Average consensus & 1.01 to 1.99 & Item accepted \\
No consensus & 2.00 and above & Item rejected \\
\hline
\end{tabular}

Source: Peck \& Devore (2007)

Referring to Table 1 above, the results obtained in the second round by using the IQR analysis, it shows that two items of career challenge elements did not reach the range value that exceeded 2.00. Therefore, the items that have no consensus among the panellists should be discarded (Nashir, Mustapha, \& Yusoff, 2015) and the researchers need to refine or revised the set of questionnaires again. Table 2 as shown below is an example of items that need to be discarded, namely C2 and C6.

Table 2

List of items accepted and rejected.

\begin{tabular}{|c|c|c|c|}
\hline Elements & $\begin{array}{l}\text { Item } \\
\text { code }\end{array}$ & Question Items & $\begin{array}{c}\text { IQR } \\
\text { Value }\end{array}$ \\
\hline \multirow[t]{7}{*}{$\begin{array}{l}\text { Leave of } \\
\text { Absence }\end{array}$} & $\mathrm{C} 1$ & $\begin{array}{l}\text { Encounter career challenges when it is difficult to get an } \\
\text { emergency leave. }\end{array}$ & 0.6 \\
\hline & $\mathrm{C} 2$ & $\begin{array}{r}\text { Encounter career challenges when it is hard to get a sick } \\
\text { leave for yourself. }\end{array}$ & 2.3 \\
\hline & C3 & $\begin{array}{r}\text { Encounter career challenges when it is difficult to get } \\
\text { maternity leave. }\end{array}$ & 0.1 \\
\hline & $\mathrm{C} 4$ & $\begin{array}{l}\text { Encounter career challenges when it is difficult for the } \\
\text { organization to approve maternity leave to the father. }\end{array}$ & 0.8 \\
\hline & $\mathrm{C} 5$ & $\begin{array}{l}\text { Encounter career challenges when it is difficult to ask for } \\
\text { additional maternity leave with semi payment. }\end{array}$ & 0.6 \\
\hline & C6 & $\begin{array}{r}\text { Encounter career challenges when it is hard to take extra } \\
\text { maternity leave without pay. }\end{array}$ & 2.1 \\
\hline & $\mathrm{C7}$ & $\begin{array}{l}\text { Encounter career challenges when it is difficult to get a } \\
\text { special leave to care for the sick family members. }\end{array}$ & 0.1 \\
\hline
\end{tabular}

The completed set of questionnaires that had been refined by the researchers were then referred once more to each panel of experts and the new arrangement was made for the third round. The panel of experts was then once again being given the time within two weeks to evaluate and state the level of agreement regarding the items in the revised questionnaire instrument. The results of the questionnaire instrument obtained in this round were then analysed once again based on the Interquartile range (IQR) analysis. In this third round, researchers found that based on the IQR analysis, it shows that all the items in each element of career challenges in this study have reached a high level of agreement among the panel of experts. A high level of consensus is reached when all 
the IQR values are less than 2.0. After that, the cycle of this Modified Delphi Technique was discontinued in the third round.

Grime and Wright (2016) explain that this process of rotation for the study of Delphi technique will be discontinued after reaching a high level of consensus among the experts and that the number of rounds in the Delphi's study is the best in two or three rounds only (Thangaratinam \& Redman, 2005). Even Alaloul, Liew and Zawawi. (2015) suggested that this Delphi technique is ideal for three rounds only, as it will cause the panels feeling fatigue and confused if too much round were conducted. Hence, the review of the process in the third rounds ceased and all the questionnaire items will be used in the pilot studies.

\section{Conclusion}

In conducting an analysis using the Modified Delphi Technique, researchers also take into consideration all comments and advice from the experts with the intentions of making refinements and improvements in the study. Once the items are sorted out after the process of item removal, the sentence structures of each item are changed and refined once again. The findings show that out of 31 items under the construct of the challenge, there are two items of the 'leave of absence' element were discarded and in the end, there are only 29 items that existed under the career challenge construct. In this regard, it is important that this study was conducted in order to observe and given emphasize on the necessary items required by an administrator, especially in technical organizations in Malaysia. Thus, in order to achieve a high-income and invulnerable nation in facing the challenges of this globalization era, the policymakers in an organization should also pay attention to the needs of the workers for them to continue being productive, consistent, and able to compete in a healthy way. On that account, all the interested parties should strive to improve and make a frame on the existing engineer career paths to a high degree of excellence.

\section{Correspondent author}

Ummu Sakinah Subri

Fakulti Teknikal dan Vokasional

Universiti Pendidikan Sultan Idris

Email: usakinah.msubri@yahoo.com

\section{References}

Alaloul, W. S., Liew, M. S., \& Zawawi, N. A. W. (2015). Delphi Technique Procedures: A New Perspective in Construction Management Research. Applied Mechanics and Materials, 802(March 2017), 661-667. https://doi.org/10.4028/www.scientific.net/AMM.802.661

Amin, S. \& P. Rameli, M. F. (2014). Fenomena Kekurangan Tenaga Kerja Wanita Berpendidikan dan Berkemahiran di Malaysia. PERKEM ke-9 (2014) 269 - 277

Avella, J. R. (2016). Delphi panels: Research design, procedures, advantages, and challenges. International Journal of Doctoral Studies, 11, 305-321. Retrieved from http://www.informingscience.org/Publications/3561 
INTERNATIONAL JOURNAL OF ACADEMIC RESEARCH IN BUSINESS AND SOCIAL SCIENCES

Vol. 9, No. 3, March, 2019, E-ISSN: 222 2-6990 @ 2019 HRMARS

Balakrishnan, B., Foon, S. L., \& Azman, M. N. A (2014). Persepsi Pelajar Perempuan Terhadap Program dan Profesion Dalam Bidang Kejuruteraan: Kajian Kes Di Malaysia dan Jepun. Jurnal Teknologi （Sciences \& Engineering). 72:1 (2015) 1-6.

Biden, N. \& Kamin, Y. (2013). Implikasi Penjenamaan Semula Sekolah Menengah Vokasional (SMV) Kepada Kolej Vokasional (KV). 2nd International Seminar on Quality and Affordable Education (ISQAE 2013), (Isqae), 316-323. https://doi.org/10.1002/jbm.a.31291

Board of Engineers Malaysia Annual Report (2017)

Clayton, M.J. (1997) Delphi: a technique to harness expert opinion for critical decision-making tasks in $\quad$ education, Educational Psychology, 17, pp. 373-386.

Economic Transformation Programme Annual Report (2014).

Fouad, A. N., Singh, R., Fitzpatrick, E. M., \& Liu, J. P. (2012). Stemming The Tide: Why Women Leave Engineering. Women In Engineering 2012 Report.

Grime, M. M., \& Wright, G. (2016). Delphi Method. In P. Brandimarte, B. Everitt, G. Molenberghs, W. Piegorsch, \& F. Ruggeri (Eds.), Wiley StatsRef : Statistics Reference Online (pp. 1-6). New York, N.Y.

Grisham,T. (2009) "The Delphi technique: a method for testing complex and multifaceted topics", International Journal of Managing Projects in Business, Vol. 2 Issue: 1, pp.112-130, https://doi.org/10.1108/17538370910930545

Hsu, C. \& Sandford, B. A. (2007). The Delphi Technique: Making Sense of Consensus. Practical Assessment Research \& Evaluation, 12(10). Available online: http://pareonline.net/getvn.asp?v=12\&n=10

Linstone, H.A. and Turoff, M. (2002) The Delphi Method: Techniques and Applications, http://www.is.njit.edu/pubs/ delphibook/index.ht

Nashir, I., Mustapha, R., \& Yusoff, A. (2015). Delphi Technique: Enhancing Research in Technical and Vocational Education. Journal of Technical Education and Training, 7(december 2015), 1223. https://doi.org/10.1109/ISANP.2017.8228803

Nworie, J. (2011). Using the delphi technique in educational technique in educational technology research. TechTrends, 55(5), 24-30.

Peck R. \& Devore J.L. 2007. Statistics: The Exploration \& Analysis of Data. 6th Ed. Pacific Grove, CA: Duxbury Press.

Rowe, G. and Wright, G. (2001) Expert opinions in forecasting: role of the Delphi technique, in Principles of Forecasting: A Handbook for Researchers and Practitioners (ed J.S. Armstrong), Kluwer Academic Publishers, Norwell, MA.

Snyder, K. (2011). A Study of Motherhood and Perceived Career Satisfaction of Women in Student Affairs. (Electronic Thesis or Dissertation). Retrieved from https://etd.ohiolink.edu/

Thangaratinam, S., \& Redman, C. W. (2005). The Delphi technique. The Obstetrician \& Gynaecologist, 7(2), 120-125. https://doi.org/10.1576/toag.7.2.120.27071

Tunku Ahmad, T. L., Wan Mustapha, W. K., Yusof, N., Zakaria, N., \& Wan Mazlan, W. N. A. (2015). Perangkaan Wanita, Keluarga \& Masyarakat Malaysia. Kementerian Pembangunan Wanita Keluarga dan Masyarakat (KPWKM) 2015. 